\title{
Using Water Stable Isotopes to Trace Water Sources of Three Typical Japanese Tree Species under Heavy Rainfall Conditions
}

\author{
Qiqin Zhang1, M. Larry Lopez C. ${ }^{1}$, Alexander C. Brandt' ${ }^{1}$ Jordi Voltas ${ }^{2,3}$, Takeshi Nakatsuka4, \\ Mónica Aguilera ${ }^{2,3}$
}

\author{
${ }^{1}$ Bioenvironment, Watershed Preservation, Yamagata University, Wakaba-Machi, Tsuruoka, Yamagata, Japan \\ ${ }^{2}$ Joint Research Unit CTFC-AGROTECNIO, Lleida, Spain \\ ${ }^{3}$ Department of Crop and Forest Sciences, Universitat de Lleida, Lleida, Spain \\ ${ }^{4}$ Research Department, Research Institute for Humanity and Nature, Kita-KuKamigamo Motoyama, Kyoto, Japan \\ Email: chou0012@tds1.tr.yamagata-u.ac.jp
}

How to cite this paper: Zhang, Q. Q., Lopez C., M. L., Brandt, A. C., Voltas, J., Nakatsuka, T., \& Aguilera, M. (2020). Using Water Stable Isotopes to Trace Water Sources of Three Typical Japanese Tree Species under Heavy Rainfall Conditions. Open Journal of Forestry, 10, 7-21.

https://doi.org/10.4236/ojf.2020.101002

Received: October 7, 2019

Accepted: December 3, 2019

Published: December 6, 2019

Copyright (๑) 2020 by author(s) and Scientific Research Publishing Inc. This work is licensed under the Creative Commons Attribution International License (CC BY 4.0).

http://creativecommons.org/licenses/by/4.0/

\begin{abstract}
Stable isotopes of xylem water $\left({ }^{18} \mathrm{O}\right.$ and $\left.\mathrm{D}\right)$ have been successfully used to determine sources of soil water for plant transpiration, but mainly in drought-prone environments. The water uptake strategies of three representative tree species in Japan, namely cedar (Cryptomeria japonica), larch (Larix kaempferi) and beech (Fagus crenata), were investigated using $\delta^{18} \mathrm{O}$ and $\delta \mathrm{D}$ of water (precipitation, soil and xylem), together with wood $\alpha$-cellulose $\delta^{13} \mathrm{C}$ and $\delta^{18} \mathrm{O}$, along one growing season. The study was carried out in the research forest of Yamagata University (Shonai region), a high precipitation area in Japan, which exceeds $3000 \mathrm{~mm}$ per year. Precipitation water $\delta^{18} \mathrm{O}$ and $\delta \mathrm{D}$ increased along the summer growing season, but oxygen and hydrogen isotopic composition of soil water remained essentially unchanged. In general, xylem water isotopes of cedar and larch followed the local meteoric water line, but beech xylem water was decoupled from soil and precipitation values in July and August. For this tree species, the xylem water isotopic records were more depleted than cedar and larch xylem water isotopic values and the precipitation water isotopic records, indicating that beech used more water from soil layers during July-August than the other two species, which mainly used newly-fallen precipitation. Wood $\delta^{18} \mathrm{O}$ showed an opposite seasonal trend to the one found for xylem water, likely because of leaf water isotope enrichment, which was in turn controlled by seasonal transpiration rate. The higher $\delta^{13} \mathrm{C}$ values of cedar during summer suggested that this species had enhanced water-use efficiency during the growing season compared with the deciduous species larch and beech. Our results highlight different water use strategies among forest tree species even in areas where the annual water balance is far from limiting plant performance.
\end{abstract}




\section{Keywords}

High Precipitation, Water Use, Stable Isotopes, Xylem Water, Soil Water

\section{Introduction}

Forests are an important component of the global water cycle as they exchange large amounts of water, originating from different terrestrial sources, with the atmosphere. Stable isotopes $\left({ }^{18} \mathrm{O}\right.$ and $\left.\mathrm{D}\right)$ have been widely used in the last decades in order to trace sources of water (rainfall, groundwater, soil water, snowmelt, mist, etc.) available to plants (Ehleringer \& Dawson, 1992; Valentini et al., 1994; Brunel et al., 1995; Walker et al., 2001; Asbjornsen et al., 2011; McDonnell, 2014; Martín-Gómez et al., 2017), that is because the isotopic composition of potential water source can be traced back from the values in xylem water. Frequently, the water isotopic composition changes with soil depth, where water from upper soil layers is isotopically enriched in relation to that from deeper layers because of evaporation gradients occurring along the soil profile during dry periods (Barnes \& Allison, 1988). In turn, xylem water isotopes often show strong seasonal variability during wet-dry periods because trees may switch from shallower to deeper soil layers when accessing water under increasing drought stress (Goldsmith et al., 2012; Penna et al., 2013; White \& Smith, 2015). This shift in access to different water pools also depends on the type of vegetation and its associated root system. For example, it has been reported (Eggemeyer et al., 2008) that Juniperus virginiana and Pinus ponderosa take up water from different soil depths under the same environmental conditions in the semi-arid sandhills grasslands of Nebraska during the growing season. Similarly, the Mediterranean oak Quercus ilex keeps physiological activity for longer periods over acute droughts in the eastern Iberian Peninsula using alternative (deeper) soil water sources, not available for the thermophilic conifer Pinus halepensis (Castillo et al., 2016). On the other hand, when water is readily available from precipitation, xylem water isotopes reflect mainly the isotopic composition of precipitation (Li et al., 2006; Li et al., 2007; Barbeta et al., 2015).

There are two important premises that have to be assumed for studying the sources of water for plants (Ehleringer \& Dawson, 1992; Voltas et al., 2015): 1) there is no fractionation during water uptake by roots, except for some xerophytic and halophytic plants (Ellsworth \& Williams, 2007; Lin et al., 1993), and 2) there is no fractionation during the water transport along the xylem, from the roots to the upper canopy (Ehleringer \& Dawson, 1992; Brunel et al., 1995; Walker et al., 2001). Hence, if no such fractionation occurs at the root level, water is isotopically enriched in the leaves proportionally to the magnitude of transpiration, and this process produces sugars that are isotopically heavier by a mean value of $27 \%$ in $\delta^{18} \mathrm{O}$ comparison to leaf water (Sternberg et al., 1986). During the formation of cellulose in the tree ring, sugars in the phloem can ex- 
change up to $50 \%$ of their oxygen atoms with xylem water, adding an extra source of variability (and uncertainty) to the interpretation of tree-ring oxygen isotopic composition, $\delta^{18} \mathrm{O}$ (Roden et al., 2000; Gessler et al., 2014). Thus, tree-ring $\delta^{18} \mathrm{O}$ partly represents the isotopic signature of source water, and partly the isotopic enrichment of leaf water, in variable proportions depending on the relevance of each process on the water economy of the tree (Labuhn et al., 2014). Additionally, the carbon isotopic composition $\left(\delta^{13} \mathrm{C}\right)$ of tree rings can be used to estimate intrinsic water-use efficiency (WUEi), or the ratio of net photosynthesis to stomatal conductance of water (Farquhar et al., 1982; Ehleringer \& Vogel, 1993; Leavitt et al., 2003), which provides information on the water-carbon balance of the plant at the leaf level.

Until now, most studies on soil water accessibility by plants along the soil profile using isotopic analysis have been conducted in arid and semiarid areas because of evaporation enrichment, but very few have been conducted in wet areas. This may be the case of the humid mixed forests of western Japan, which may be subjected to sporadic episodes of water scarcity in early summer or concentrated extreme rain events with long rainless pauses even within the rainy season period. In the western side of northeastern Japan, the dominant tree species are cedar (Cryptomeria japonica), larch (Larix kaempferi) and beech (Fagus crenata Blume). Cedar is the most commercially important tree species in Japan, with plantations covering an area of approximately $4500 \mathrm{~km}^{2}$ (MAFF, 2017), while larch, also native to Japan, is also widely planted for forest industry in northern Japan $\left(4700 \mathrm{~km}^{2}\right)$ (MAFF, 2017) and is distributed as the southern edge of the larch distribution in East Asia. Beech is the most abundant deciduous broad-leaved tree species in Japan, growing in the cool-temperate zone as a late-successional and climax species (Liang et al., 1995). A comparative study on the nitrogen cycle, using nitrogen stable isotopes, of these tree species in the same region revealed differences among them, with beech trees showing higher nitrogen resorption from senescing leaves (Enta et al., 2019; Seidel et al., 2019a, 2019b), which might be related to their water use patterns. All these tree species are well adapted to the heavy precipitation conditions of northeastern Japan. However, the species and populations of forest trees inhabiting wet areas may be particularly susceptible to the impact of an even distribution of rain along the growing season in the face of on-going climate change (Engelbrecht et al., 2007). Thus, the aims of this study were threefold: 1) to determine the temporal pattern of temporal variation of stable isotopes in soil and xylem water of three typical Japanese tree species, the evergreen conifer Cryptomeria japonica and the deciduous-but taxonomically contrasting-Larix kaempferi and Fagus crenata; 2) to compare temporal changes in tree-ring $\delta^{18} \mathrm{O}$ with xylem water $\delta^{18} \mathrm{O}$ records as related to the relevance of summer transpiration; and 3) to evaluate intrinsic water-use efficiency of each tree species by means of $\delta^{13} \mathrm{C}$, and to relate the observed seasonal patterns to changes in soil water sources used by trees. The results are important to characterize and understand potentially relevant differences in access to soil water pools among these tree species typical of wet areas 
under current climate change and associated warming-induced drought events.

\section{Methods}

\subsection{Study Site and Meteorological Data}

The forest stands are located within the premises of the Yamagata University Research Forest (YURF), which is in the Asahi Mountains, $26 \mathrm{~km}$ south of Tsuruoka city in Yamagata Prefecture (Figure 1). Three typical Japanese tree species for this region were selected to evaluate their water use patterns: beech (Fagus crenata), larch (Larix kaempferi) and cedar (Cryptomeria japonica). The beech forest stand $\left(\mathrm{N} 38^{\circ} 33.396^{\prime}, \mathrm{E} 139^{\circ} 52.641^{\prime}\right)$ was located at the highest elevation in the experimental forest ( 670 m.a.s.l.), and the trees had an average age of $70-80$ years. The larch forest stand $\left(\mathrm{N} 38^{\circ} 33.415^{\prime}, \mathrm{E} 139^{\circ} 52.566^{\prime}\right)$ was located at a slightly lower elevation (650 m.a.s.l.), and the trees had an average age of 45 - 50 years. Finally, the cedar forest site $\left(\mathrm{N} 38^{\circ} 32.982^{\prime}, \mathrm{E} 139^{\circ} 51.796^{\prime}\right)$ was located at the lowest elevation ( 295 m.a.s.l.), and the trees had an average age of 54 years.

The annual precipitation in this area is $3090 \mathrm{~mm}$ of which $42 \%$ falls as snow, the annual mean air temperature is $9.5^{\circ} \mathrm{C}$ for the period 2012-2017 (Figure 2). The mean summer precipitation (June, July and August) is $518 \mathrm{~mm}$ and the mean

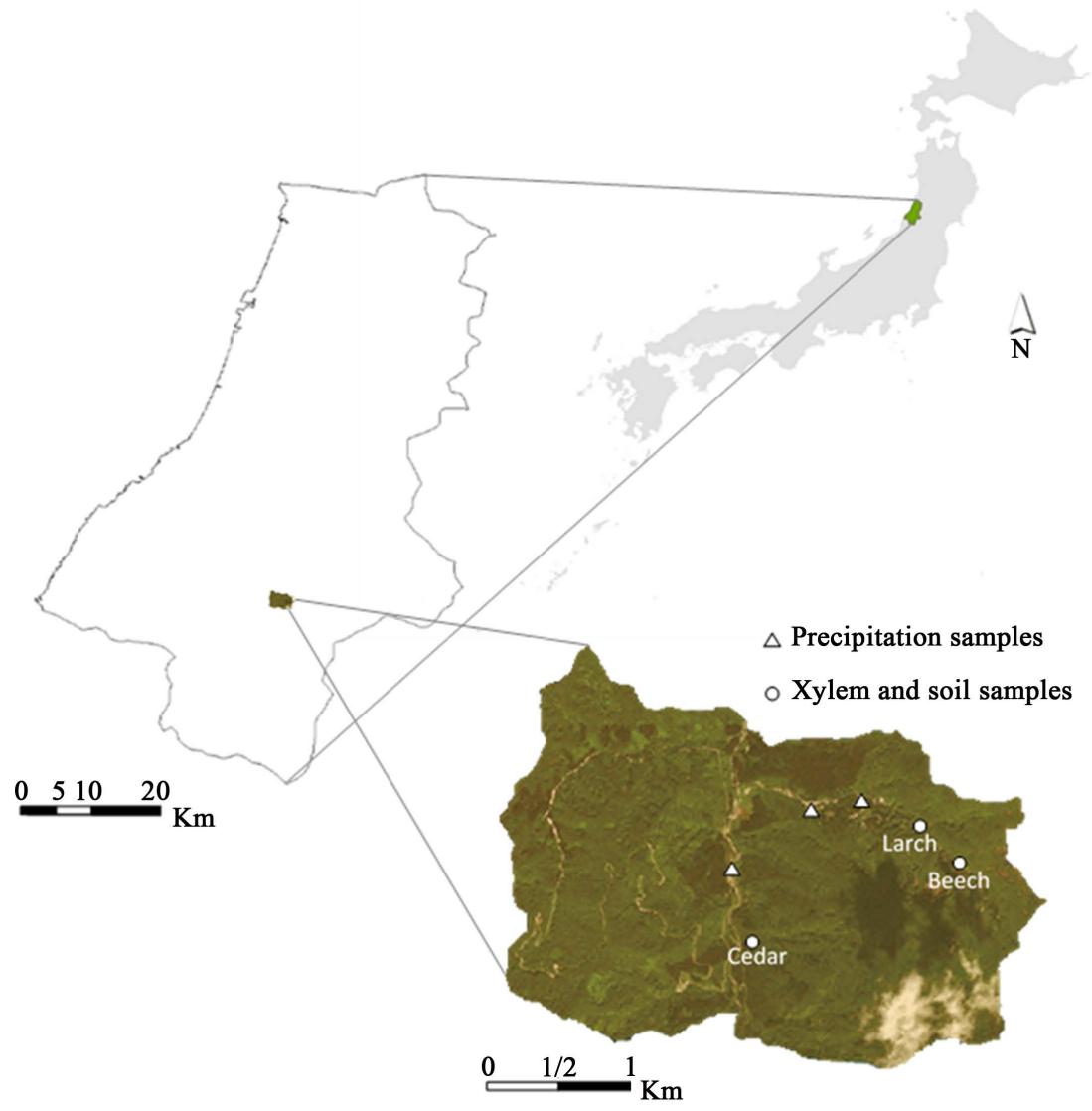

Figure 1. The Yamagata University Research Forest (YURF) is in Shonai region, Yamagata Prefecture, Japan. The circles represent the xylem and soil sampling sites within the forest, the triangles represent the precipitation sampling spot. 


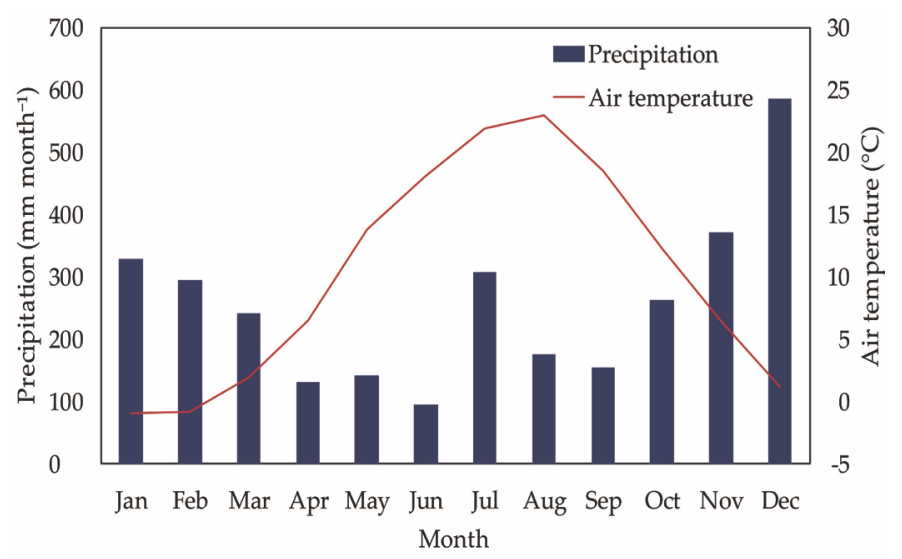

Figure 2. Mean monthly temperature and precipitation in the study area (2012-2017). (Source: Yamagata University Research Forest Meteorological Station).

air temperature is $20.9^{\circ} \mathrm{C}$. Monthly precipitation is relatively low from April to September, except for July when the highest values for the growing season are observed as the rainy season sets in for this region. The highest precipitation occurs from October to March, mainly in the form of snow, with the snow melting starting from mid-February and ending by late April or the beginning of May. Average air temperatures are below zero only in January and February, while the highest temperature corresponds to July and August during summer. Air temperature increases from May through June, and stays approximately stable during July and August. During summer 2017, precipitation was $121 \mathrm{~mm}$ (June), $388 \mathrm{~mm}$ (July) and $193 \mathrm{~mm}$ (August). Most precipitation was concentrated in the first days of July $(155 \mathrm{~mm})$, representing the peak of the rainy season.

\subsection{Sampling Design and Measurements}

Samples were collected on June 21, July 25 and August 23 (2017). Ten beech, eight larch and ten cedar trees were randomly sampled in each forest stand for xylem water respectively. The xylem was collected by peeling the bark and phloem from twigs of about $1-\mathrm{cm}$ of diameter taken from the lower part of the crown. In total, we collected 30 samples from cedar and beech trees each and 24 samples from larch trees. The twigs were sampled using telescopic loppers at noon (solar time) approximately. From 07:00 to 09:00 h solar time, soil samples were collected from $0-20 \mathrm{~cm}, 20-40 \mathrm{~cm}$ and $40-60 \mathrm{~cm}$ depth using a straight tube probe thoroughly cleaned between consecutive samplings from three soil pits evenly distributed within the area covered by the sampled trees at each stand. All twig and soil samples were collected by screw-top test tube (NW-18) and frozen immediately after sampling to prevent evaporation. Finally, at the end of the growing season tree cores from all trees were collected at each site using a $10-\mathrm{mm}$ diameter increment borer. The corresponding tree rings of 2017 were sliced in monthly sections using an automatic microtome for successive increments based on growth measurements obtained from dendrometers (Ma- 
nual Dendrometer D1, METER Group, Inc., USA) installed in five trees for each species. For the period January-August, precipitation water for isotope analysis was collected immediately after every rain event from 3 plastic bottles, where a 7 $\mathrm{cm}$ diameter funnel was inserted, evenly set in open spaces close to the forest sites. To prevent evaporation, the water was stored in airtight flasks and kept frozen until measurements were conducted. The local meteoric water line (LMWL) was estimated as $\delta \mathrm{D}=8 \times \delta^{18} \mathrm{O}+15$ (Matsubaya \& Kawaraya, 2014).

Xylem and soil water were extracted using a cryogenic vacuum distillation system (Martín-Gómez et al., 2015) and, together with precipitation water, were analyzed for $\delta^{18} \mathrm{O}$ (oxygen isotopic composition) and $\delta \mathrm{D}$ (hydrogen isotopic composition) by isotope ratio infrared spectroscopy (IRIS) using a Picarro L2120-i coupled to an A0211 high-precision vaporizer (Picarro Inc., Sunnyvale, CA, USA). The estimated precision, based on the repeated analysis of four reference water samples, was $0.10 \%$ for $\delta^{18} \mathrm{O}$ and $0.40 \%$ o for $\delta \mathrm{D}$. Residual organic contaminants in the distilled water can interfere with the analysis of plant and soil samples conducted with IRIS (Martín-Gómez et al., 2015). The presence of contaminants was checked using Picarro's CHEMCORRECT post-processing software and corrected (in some few cases) following (Martín-Gómez et al., 2015).

Wood slices were cut in fine pieces and purified to $\alpha$-cellulose (Ferrio \& Voltas, 2005). For carbon and oxygen isotope analysis, $0.30-0.40 \mathrm{mg}$ of dry $\alpha$-cellulose was weighed into tin foil capsules and combusted using an elemental analyzer (EA1110, Thermo Quest, Italy) interfaced with a Delta PLUSXL gas isotope ratio mass spectrometer (Thermo Finnigan, Bremen, Germany). Isotope ratios were expressed as per mil deviations using the $\delta$ notation relative to Vienna Pee Dee Belemnite (for carbon) and Vienna Standard Mean Ocean Water (for oxygen) standards. The accuracy of the analyses (SD of working standards) was $0.06 \%$ o $\left(\delta^{13} \mathrm{C}\right)$ and $0.25 \%$ o $\left(\delta^{18} \mathrm{O}\right)$. Statistical comparisons among species and months were carried out using a two-way analysis of variance (two-way ANOVA) for stable isotopes of xylem water, soil water and wood $\alpha$-cellulose. All statistical analysis was conducted with the software JMP (SAS Institute Inc.).

\section{Results}

\subsection{Isotopic Variation in Monthly Precipitation and Xylem Water}

Precipitation water $\delta^{18} \mathrm{O}$ and $\delta \mathrm{D}$ values at YURF are shown in Figure 3. They followed essentially the same trends as the 22-year record of monthly precipitation water $\delta^{18} \mathrm{O}$ and $\delta \mathrm{D}$ found for Akita prefecture (Matsubaya \& Kawaraya, 2014), $140 \mathrm{~km}$ north of Shonai region. The water isotopic composition of June represented the lowest $\delta^{18} \mathrm{O}$ and $\delta \mathrm{D}$ values observed throughout the year in Shonai.

Increasing trends in xylem water $\delta^{18} \mathrm{O}$ and $\delta \mathrm{D}$ in all tree species were found in summer (Figure 4), in agreement with the monthly variation of precipitation water isotopes composition for the same period (Figure 3, shaded area). For xylem $\delta^{18} \mathrm{O}$, there was no significant difference between species $(p=0.185)$, but for 


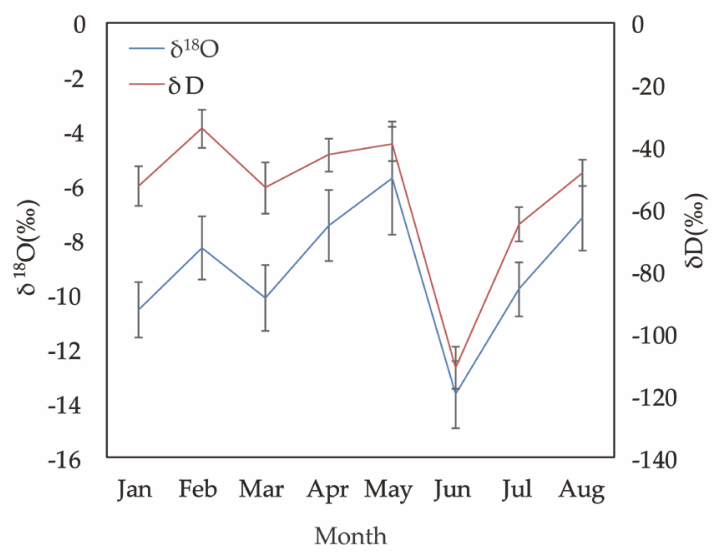

Figure 3. Monthly $\delta^{18} \mathrm{O}$ and $\delta \mathrm{D}$ of monthly precipitation at Yamagata University Research Forest in 2017 (January to August); Values are mean \pm SE $(n=3)$.

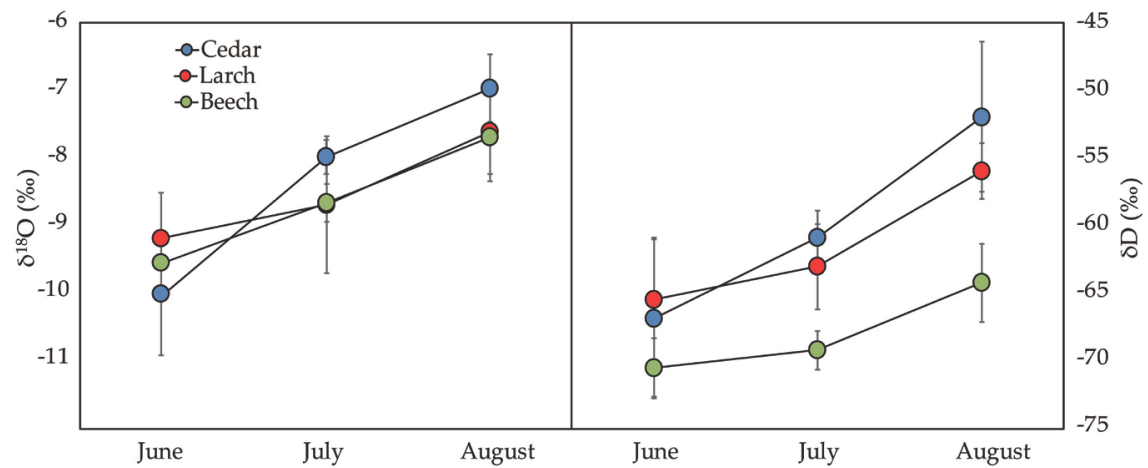

(a)

(b)

Months

Figure 4. Monthly (a) $\delta^{18} \mathrm{O}$, (b) $\delta \mathrm{D}$ of xylem water from cedar (blue circle), larch (red circle) and beech (green circle); values are mean \pm SE, cedar $(n=10)$, larch $(n=8)$, beech $(\mathrm{n}=10)$.

xylem $\delta \mathrm{D}$ there was a significant difference between cedar and beech and larch and beech $(p<0.001)$, with beech being isotopically lighter than the other two tree species during the summer months, especially in August.

\subsection{Correlation between $\delta 180$ and $\delta \mathrm{D}$}

Soil water, xylem water and precipitation isotope records are represented together with the GMWL (Global Meteoric Water Line) and LMWL (Local Meteoric Water Line) in Figure 5. Soil water $\delta^{18} \mathrm{O}$ and $\delta \mathrm{D}$ at $0-20 \mathrm{~cm}$ and $20-40 \mathrm{~cm}$ depths (but not soil water at $40-60 \mathrm{~cm}$ ) were uncoupled from the LMWL in June, which indicated that evaporation was higher in these two layers than in the deeper $40-60 \mathrm{~cm}$ soil layer. In contrast, in July and August soil water isotope ratios followed the LMWL, which indicated lower evaporation in these two months. Similarly, the isotopic values of all soil layers showed comparable values in July. Precipitation water isotope ratios increased markedly along the summer months, with values of $-13.7 \%$, $-9.8 \%$, and $-7.2 \%$ for $\delta^{18} \mathrm{O}$, and $-111.1 \%$, $-64.9 \%$, and $-48.5 \%$ for $\delta \mathrm{D}$ in June, July and August, respectively. Xylem water 


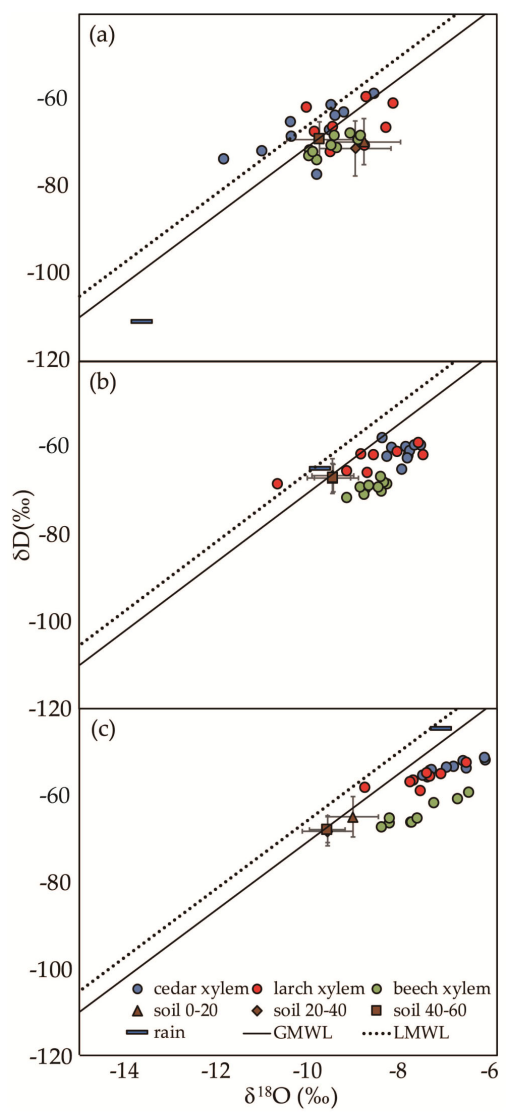

Figure 5. Relationship between $\delta \mathrm{D}$ and $\delta^{18} \mathrm{O}$ in precipitation water $(\mathrm{n}=3)$, xylem water for all tree species (cedar, $\mathrm{n}=10$; larch, $\mathrm{n}=8$; beech, $\mathrm{n}=10$ ) and the average of soil water isotope ratios at different depths $(n=9)$ in (a) June, (b) July and (c) August. The Local Meteoric Water Line (LMWL) and Global Meteoric Water Line (GMWL) are also represented.

isotope ratios showed relatively similar values as those of soil water isotopes in June ( $-8 \%$ o to $-11 \%$ o for $\delta^{18} \mathrm{O},-60 \%$ o to $-80 \%$ o for $\left.\delta \mathrm{D}\right)$; however, xylem water isotopic composition became decoupled from soil water isotopic records in July. Finally, in August, xylem water $\delta^{18} \mathrm{O}$ and $\delta \mathrm{D}$ values for cedar and larch were between the range of values found for soil and precipitation water isotope ratios, but xylem water $\delta \mathrm{D}$ values of beech were always lighter in comparison to the other two tree species $\delta \mathrm{D}$ and closer to those of soil water values during the study period.

\subsection{Monthly Tree-Ring $\alpha$-Cellulose $\delta^{18} 0$ and $\delta^{13} \mathrm{C}$}

Wood $\alpha$-cellulose $\delta^{18} \mathrm{O}$ (hereafter, wood $\delta^{18} \mathrm{O}$ ) showed a decreasing trend along the summer months for the three species (Figure 6(a)). Overall, the highest $\delta^{18} \mathrm{O}$ values were found in June which were significantly higher than wood $\delta^{8} \mathrm{O}$ in July and August. However, this was only found for cedar $(p<0.001)$. On the other hand, no significant temporal variation of wood $\delta^{18} \mathrm{O}$ was found for larch or beech. There were no significant seasonal differences in wood $\delta^{13} \mathrm{C}$ (Figure 6(b)). But species-specific differences were found for both wood $\delta^{18} \mathrm{O}$ and 


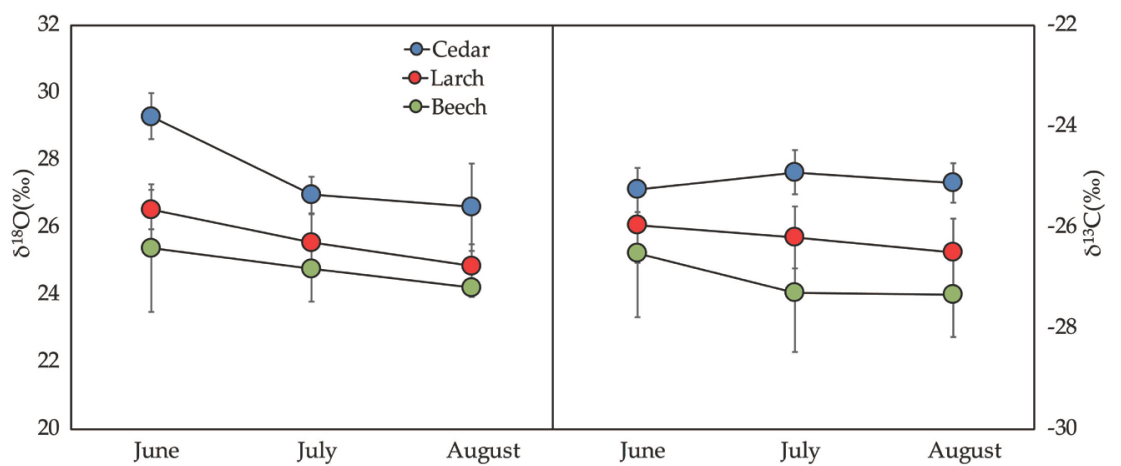

(a)

(b)

Months

Figure 6. Monthly tree ring $\delta^{18} \mathrm{O}(\mathrm{a})$ and $\delta^{13} \mathrm{C}(\mathrm{b})$ in cedar (blue circle), larch (red circle) and beech (green circle); values are mean \pm SE, cedar $(n=10)$, larch $(n=8)$, beech $(n=10)$.

$\delta^{13} \mathrm{C}$, with the highest values recorded in cedar, followed by larch and beech $(p<$ $0.001)$.

\section{Discussion}

\subsection{Temporal Difference of Xylem Water Isotopes}

No significant differences in xylem water $\delta^{18} \mathrm{O}$ were found among species, but progressively increasing values were observed from June to August in agreement with the gradually more isotopically enriched precipitation water found along this period. This suggests a tight dependence of xylem water on precipitation water during the peak season when drought stress is absent (Li et al., 2006; Li et al., 2007; Barbeta et al., 2015). In addition, the xylem water isotopic composition of the three species followed closely the different water sources from June to August. However, there were significant differences in xylem water $\delta \mathrm{D}$ between beech and the other two species, as beech $\delta \mathrm{D}$ showed constantly lighter values, suggesting that the main source of water for this species was soil water-even during months of high precipitation-unlike cedar and larch trees that were likely more prompt to use readily available fresh precipitation water. This was particularly evident in August, when precipitation water was isotopically heavier than the soil water, suggesting that beech trees used soil water as their main water source. Indeed, xylem water $\delta \mathrm{D}$ was in the same range as soil water $\delta \mathrm{D}$, which was more depleted than precipitation water. According to Goldsmith et al. (2012), under dry and wet conditions, different tree species used the same water source as indicated by their xylem isotopic composition. In contrast, cedar and larch trees appeared to use fresh precipitation water when it was available, as shown by xylem water $\delta \mathrm{D}$ values that were closer to those of precipitation water $\delta \mathrm{D}$. In June (when precipitation was relatively low), cedar and larch trees apparently used water mainly from shallow soil layers where the bulk of their roots are distributed, since xylem water isotopic composition was in the same range as the soil water isotopic values (Eggemeyer et al., 2008; Castillo et al., 2016). Even though beech appeared to use soil water as their main source, during periods of 
high precipitation, the source of water was the combination of soil water and fresh precipitation. The same pattern has been reported for Fagus sylvatica trees in northern Italy where they use soil and precipitation water during rainy periods but mainly deep soil water and groundwater during dry periods (Penna et al., 2013).

In our study, we found an offset between xylem water $\delta \mathrm{D}$ and water sources $\delta \mathrm{D}$ as it has been reported in recent studies (Plavcová et al., 2018; Evaristo et al., 2017; Geris et al., 2017). However, we only detected this offset in August, but not in June and July. In a previous study on seasonal patterns of Fagus sylvatica in Czech Republic, the xylem water isotopic composition followed the precipitation isotopic composition (Oerter \& Bowen, 2019), which was the case for oxygen isotopes in our study. Coincidentally, Fagus sylvatica xylem water $\delta \mathrm{D}$ was reportedly more depleted than the source water, suggesting that fractionation occurred at the soil interface during water uptake (Barbeta et al., 2019). Although we observed a similar phenomenon in August, our data are probably not enough to support the theory that such fractionation occurred in Fagus crenata. This remains a topic of future study since it may appear to be a species- and temporal-specific phenomenon, as suggested by our results.

\subsection{Different Water Uses among Tree Species}

Our results indicated that, among the three tree species, there were two water use patterns during the summer period that were controlled by the precipitation regime and the root distribution of each tree species. In June, when precipitation was relatively low $(128.5 \mathrm{~mm})$, the three tree species took up water from shallow as well as deeper soil layers, as it can be inferred by the similar isotopic composition of xylem and soil water among species. In July, the soil water isotopic composition was strongly controlled by precipitation water. Therefore, it was difficult to discern if trees were preferentially using soil water, fresh precipitation water or both during this month. We assume, though, that trees used mainly (readily available) precipitation water. In August precipitation water isotopic composition was heavier than soil water isotopic composition but because of lower precipitation in comparison to July, soil water isotopic composition did not reflect precipitation water isotopic composition. Thus, it was possible to identify that cedar and larch used preferentially precipitation water that was readily available, whereas beech used preferentially water from deeper soil layers, which is accessible to this tree species because of its deeper root system distribution in comparison to cedar and Larch. In general, cedar and larch root systems are distributed in the surface $30 \mathrm{~cm}$ soil layer, while beech fine roots are evenly distributed down to $60 \mathrm{~cm}$ deep (Karizumi, 2011).

\subsection{Monthly Wood $\alpha$-Cellulose $\delta^{18} 0$ and $\delta^{13} \mathrm{C}$}

The monthly values of wood $\delta^{18} \mathrm{O}$ and $\delta^{13} \mathrm{C}$ were in the range of values found for other tree species in northeastern (Lopez et al., 2018) and northern (Nakatsuka 
et al., 2004) Japan. Wood $\delta^{18} \mathrm{O}$ and $\delta^{13} \mathrm{C}$ showed species-specific differences, where the highest values corresponded to cedar, followed by larch and beech. Under similar environmental conditions, species with low $\delta^{13} \mathrm{C}$ values usually maintain a high-water potential, indicating low WUEi, whereas species with high $\delta^{13} \mathrm{C}$ may show lower water potential and high WUEi (Gebrekirstos et al., 2011). Therefore, we assume that the difference found among $\delta^{13} \mathrm{C}$ is related to differences in intrinsic water-use efficiency (WUEi). The higher WUEi of cedar is probably driven by enhanced stomatal regulation of water losses for this species, as suggested by higher $\delta^{18} \mathrm{O}$ values (Scheidegger et al., 2000; Shestakova et al., 2017). This means that $\delta^{18} \mathrm{O}$ may also be used as an indicator of stomatal regulation in heavy rainfall areas. Monthly wood $\delta^{18} \mathrm{O}$ values showed opposite trends with respect to xylem water $\delta^{18} \mathrm{O}$ for all three species, which is apparently caused by leaf water enrichment, since strong oxygen exchange between phloem and xylem would have produced similar trends for both wood and xylem $\delta^{18} \mathrm{O}$. In addition, the transport of exported carbohydrates from leaves to developing stems, where cellulose is formed, and the corresponding biochemical fractionation associated with cellulose synthesis could not strongly influence the wood $\delta^{18} \mathrm{O}$ monthly trend (Roden et al., 2000). Dendrometer records showed that the maximum growth occurred in June and decreased sharply in July and August (Figure 7), which suggests that enhanced transpiration (related to higher photosynthetic rates) led to higher leaf water enrichment in June (i.e. higher wood $\left.\delta^{18} \mathrm{O}\right)$ and a decrease in July and August. Thus, monthly wood $\delta^{18} \mathrm{O}$ values likely reflected different degrees of leaf water enrichment caused by differences in monthly transpiration rates.

\section{Conclusion}

Cedar, larch and beech showed different water use patterns. The conifers cedar and larch were more prompt to use readily available precipitation water because of its shallow root system, as revealed by $\delta^{18} \mathrm{O}$ and $\delta \mathrm{D}$ records of xylem, precipitation and soil water. However, these tree species used water stored in different

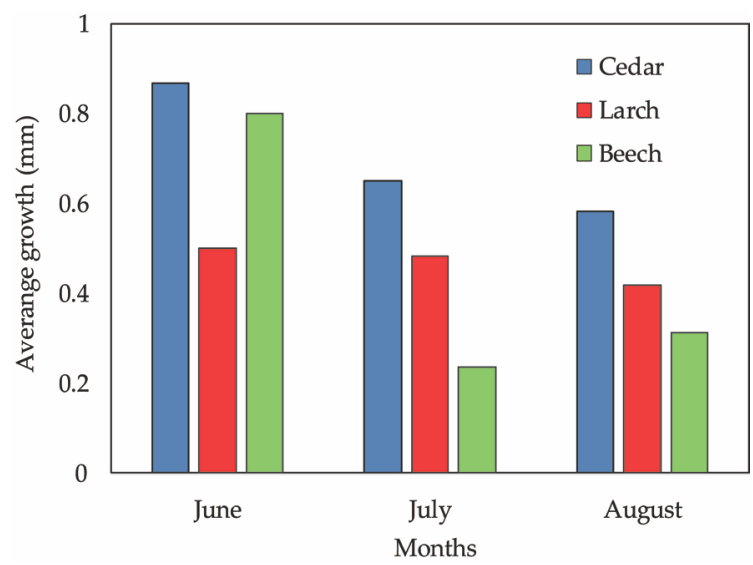

Figure 7. Monthly growth of cedar (blue bar, $\mathrm{n}=10$ ), larch (red bar, $\mathrm{n}=8$ ) and beech (green bar, $\mathrm{n}=10$ ) based on dendrometer records. 
soil layers when precipitation was relatively low. On the other hand, the broadleaf beech used soil water more profusely than the other two species because of its deeper root system, as indicated by xylem $\delta \mathrm{D}$. For all tree species, xylem water and wood $\alpha$-cellulose $\delta^{18} \mathrm{O}$ showed opposite trends due to differences in leaf water enrichment among tree species caused probably by differences in monthly canopy transpiration. The differences in wood $\delta^{13} \mathrm{C}$ pointed to differences in WUEi, with the evergreen cedar showing a consistently higher WUEi than the deciduous larch and beech.

\section{Acknowledgements}

We thank Pilar Sopeña and Maria Josep Pau for technical assistance at the University of Lleida and Nakano Sayako, Felix Seidel, Mano Yurie and Otsu Shota for helping us with the field work in Japan.

\section{Conflicts of Interest}

The authors declare no conflicts of interest regarding the publication of this paper.

\section{References}

Asbjornsen, H., Goldsmith, G. R., Alvarado-Barrientos, M. S., Rebel, K., van Osch, F. P., Riet-Kerk, M., Chen, J., Gotsch, S., Tobón, C., Geissert, D. R., Gómez-Tagle, A., Vache, K., \& Dawson, T. E. (2011). Ecological Advances and Applications in Plant-Water Relations Research: A Review. Journal of Plant Ecology, 4, 3-22. https://doi.org/10.1093/jpe/rtr005

Barbeta, A., Jones, S. P., Clavé, L., Wingate, L., Gimeno, T. E., Fréjaville, B., Wohl, S., \& Ogée, J. (2019). Unexplained Hydrogen Isotope Offsets Complicate the Identification and Quantification of Tree Water Sources in a Riparian Forest. Hydrology and Earth System Sciences, 23, 2129-2146. https://doi.org/10.5194/hess-23-2129-2019

Barbeta, A., Mejía-Chang, M., Ogaya, R., Voltas, J., Dawson, T. E., \& Peñuelas, J. (2015). The Combined Effects of a Long-Term Experimental Drought and an Extreme Drought on the Use of Plant-Water Sources in a Mediterranean Forest. Global Change Biology, 21, 1213-1225. https://doi.org/10.1111/gcb.12785

Barnes, C. J., \& Allison, G. B. (1988). Tracing of Water Movement in the Nsaturated Zone Using Stable Isotopes of Hydrogen and Oxygen. Journal of Hydrology, 100, 143-176. https://doi.org/10.1016/0022-1694(88)90184-9

Brunel, J. P., Walker, G. R., \& Kennett-Smith, A. K. (1995). Field Validation of Isotopic Procedures for Determining Sources of Water Used by Plants in a Semi-Arid Environment. Journal of Hydrology, 167, 351-368. https://doi.org/10.1016/0022-1694(94)02575-V

Castillo, J. D., Comas, C., Voltas, J., \& Ferrio, J. P. (2016). Dynamics of Competition over Water in a Mixed Oak-Pine Mediterranean Forest: Spatio-Temporal and Physiological Components. Forest Ecology and Management, 382, 214-224.

https://doi.org/10.1016/j.foreco.2016.10.025

Eggemeyer, K. D., Awada, T., Harvey, F. E., Wedin, D. A., Zhou, X. H., \& Zanner, C. W. (2008). Seasonal Changes in Depth of Water Uptake for Encroaching Trees Juniperus Virginiana and Pinus Ponderosa and Two Dominant C4 Grasses in a Semiarid Grassland. Tree Physiology, 29, 157-169. https://doi.org/10.1093/treephys/tpn019 
Ehleringer, J. R., \& Dawson, T. E. (1992). Water Uptake by Plants: Perspectives from Stable Isotope Composition. Plant, Cell \& Environment, 15, 1073-1082. https://doi.org/10.1111/j.1365-3040.1992.tb01657.x

Ehleringer, J. R., \& Vogel, J. C. (1993). Historical Aspects of Stable Isotopes. In J. R. Ehleringer, A. E. Hall, \& G. D. Farquhar (Eds.), Stable Isotopes and Plant Carbon-Water Relations (pp. 9-18). New York: Academic Press. https://doi.org/10.1016/B978-0-08-091801-3.50008-8

Ellsworth, P. Z., \& Williams, D. G. (2007). Hydrogen Isotope Fractionation during Water Uptake by Woody Xerophytes. Plant \& Soil, 291, 93-107. https://doi.org/10.1007/s11104-006-9177-1

Engelbrecht, B. M. J., Comita, L. S., Condit, R., Kursar, T. A., Tyree, M. T., Turner, B. L., \& Hub-Bell, S. P. (2007). Drought Sensitivity Shapes Species Distribution Patterns in Tropical Forest. Nature, 447, 80-83. https://doi.org/10.1038/nature05747

Enta, A., Hayashi, M., Lopez, C, M, L., Fujiyoshi, L., Yamanaka, T., Oikawa, A., \& Seidel, F. (2019). Nitrogen Resorption and Fractionation during Leaf Senescence in Typical Tree Species in Japan. Journal of Forestry Research, 1-10. https://doi.org/10.1007/s11676-019-01055-Z

Evaristo, J., Mcdonnell, J. J., \& Clemens, J. (2017). Plant Source Water Apportionment Using Stable Isotopes: A Comparison of Simple Linear, Two-Compartment Mixing Model Approaches. Hydrological Processes, 31, 3750-3758. https://doi.org/10.1002/hyp.11233

Farquhar, G. D., O’Leary, M. H., \& Berry, J. A. (1982). On the Relationship between Carbon Isotope Discrimination and Intercellular Carbon Dioxide Concentration in Leaves. Australian Journal of Plant Physiology, 9, 121-137. https://doi.org/10.1071/PP9820121

Ferrio, J. P., \& Voltas, J. (2005). Carbon and Oxygen Isotopes Ration in Wood Constituents of Pinus halepensis and Indicator of Precipitation, Temperature and Vapour Pressure Deficit. Tellus, 57B, 164-173. https://doi.org/10.1111/j.1600-0889.2005.00137.x

Gebrekirstos, A., van Noordwijk, M., Neufeldt, H., \& Mitlöhner, R. (2011). Relationship of Stable Carbon Isotopes, Plant Water Potential and Growth: An Approach to Assess Water Use Efficiency and Growth Strategies of Dry Land Agroforestry Species. Trees, 25, 95-102. https://doi.org/10.1007/s00468-010-0467-0

Geris, J., Tetzlaff, D., Mcdonnell, J. J., \& Soulsby, C. (2017). Spatial and Temporal Patterns of Soil Water Storage and Vegetation Water Use in Humid Northern Catchments. Science of The Total Environment, 595, 486-493.

https://doi.org/10.1016/j.scitotenv.2017.03.275

Gessler, A., Ferrio, J. P., Hommel, R., Treydte, K., Werner, R. A., \& Monson, R. K. (2014). Stable Isotopes in Tree Rings: Towards a Mechanistic Understanding of Isotope Fractionation and Mixing Processes from the Leaves to the Wood. Tree Physiology, 34, 796-818. https://doi.org/10.1093/treephys/tpu040

Goldsmith, G. R., Muñoz-Villers, L. E., Holwerda, F., Mcdonnell, J. J., Asbjornsen, H., \& Dawson, T. E. (2012) Stable Isotopes Reveal Linkages among Ecohydrological Processes in a Seasonally Dry Tropical Montane Cloud Forest. Ecohydrology, 5, 779-790. https://doi.org/10.1002/eco.268

Karizumi, S. (2011). Tree Root Illustration (pp. 62-66, 123-132, 296-300). Tokyo, Japan: Seibunndo Shinkosha.

Labuhn, I., Daux, V., Pierre, M., Stivenard, M., Girardclo, O., Féron, A., Genty, D., Mas-son-Delmotte, V., \& Mestre, O. (2014). Tree Age, Site and Climate Controls on 
Tree Ring Cellulose $\delta^{18} \mathrm{O}$ : A Case Study on Oak Trees from South-Western France. Dendrochronologia, 32, 78-89. https://doi.org/10.1016/j.dendro.2013.11.001

Leavitt, S. W., Idso, S. B., Kimball, B. A., Burns, J. K., Sinha, A., \& Stott, L. (2003). The Effect of Long-Term Atmospheric $\mathrm{CO}_{2}$ Enrichment on the Intrinsic Water-Use Efficiency of Sour Orange Trees. Chemosphere, 50, 217-222. https://doi.org/10.1016/S0045-6535(02)00378-8

Li, S. G., Saltos, H. R., Tsujimura, M., Sugimoto, A., Sasaki, L., Davaa, G., \& Oyunbaatar, D. (2007). Plant Water Sources in the Cold Semiarid Ecosystem of the Upper Kherlen River Catchment in Mongolia: A Stable Isotope Approach. Journal of Hydrology, 333, 109-117. https://doi.org/10.1016/j.jhydrol.2006.07.020

Li, S. G., Tsujimura, M., Sugimoto, A., Sasaki, L., Yamanaka, T., Davaa, G., Oyunbaatar, D., \& Sugita, M. (2006). Seasonal Variation in Oxygen Isotope Composition of Waters for a Montane Larch Forest in Mongolia. Trees, 20, 122-130.

https://doi.org/10.1007/s00468-005-0019-1

Liang, N., Nagayama, M., Nakata, M., \& Maruyama, K. (1995). Growth, Photosynthesis and Nitrogen Content in Japanese Beech (Fagus crenata Bl.) Seedlings Grown under Five Irradiances. Photosynthetica, 31, 257-268.

Lin, G. H., Sternberg, L. D. L., Hall, A. E., \& Farquhar, G. D. (1993). Hydrogen Isotopic Fractionation by Plant Roots during Water Uptake in Coastal Wetland Plants. In J. R. Ehleringer, A. E. Hall, \& G. D. Farquhar (Eds.), Stable Isotopes and Plant Carbon-Water Relations (pp. 497-510). New York: Academic Press. https://doi.org/10.1016/B978-0-08-091801-3.50041-6

Lopez, C. M. L., Nakano, S., Ferrio, J. P., Hayashi, M., Nakatsuka, T., Sano, M., Yamanaka, T., \& Nobori, Y. (2018). Evaluation of the Effect of the 2011 Tsunami on Coastal Forests by Means of Multiple Isotopic Analysis of Tree-Rings. Isotopes in Environmental and Health Studies, 54, 494-507. https://doi.org/10.1080/10256016.2018.1495203

MAFF (2017). http://www.rinya.maff.go.jp/j/keikaku/genkyou/h29/4.html

Martín-Gómez, P., Barbeta, A., Voltas, J., Peñuelas, J., Dennis, K., Palacio, S., Dawson, T. E., \& Feerio, J. P. (2015). Isotope-Ratio Infrared Spectroscopy: A Reliable Tool for the Investigation of Plant-Water Sources? New Phytologist, 207, 914-927. https://doi.org/10.1111/nph.13376

Martín-Gómez, P., Díaz, J. P. M., \& García, J. P. (2017). Water Use Patterns and Physiological Interactions in Sub Mediterranean Mixed Forests: Methodological Challenges and Implications for Ecohydrology. Ph.D. Thesis, Lleida: University of Lleida, Pl. de Víctor Siurana.

Matsubaya, O., \& Kawaraya, H. (2014). Hydrogen and Oxygen Isotopic Characteristics of Precipitation in Coastal Areas of Japan Determined by Observations of 23 Years at Akita and for 1-2 Years at Other Several Localities. Geochemical Journal, 48, 397-408. https://doi.org/10.2343/geochemj.2.0314

McDonnell, J. J. (2014). The Two Water Worlds Hypothesis: Ecohydrological Separation of Water between Streams and Trees? WIREs Water, 1, 323-329. https://doi.org/10.1002/wat2.1027

Nakatsuka, T., Ohnishi, K., Hara, T., Sumida, A., Mitsuishi, D., Kurita, N., \& Uemura, S. (2004). Oxygen and Carbon Isotopic Ratios of Tree-Ring Cellulose in a Conifer-Hardwood Mixed Forest in Northern Japan. Geochemical Journal, 38, 77-88. https://doi.org/10.2343/geochemj.38.77

Oerter, E. J., \& Bowen, G. J. (2019). Spatio-Temporal Heterogeneity in Soil Water Stable Isotopic Com-Position and Its Ecohydrologic Implications in Semiarid Ecosystems. 
Hydrological Processes, 33, 1724-1738. https://doi.org/10.1002/hyp.13434

Penna, D., Oliviero, O., Assendelft, R., Zuecco, G., van Meerveld, I. H. J., Anfodillo, T., Car-Raro. V., Borga, M., \& Fontana, G. D. (2013). Tracing the Water Sources of Trees and Streams: Isotopic Analysis in a Small Pre-Alpine Catchment. Procedia Environmental Sciences, 19, 106-112. https://doi.org/10.1016/j.proenv.2013.06.012

Plavcová, L., Hronková, M., Marie Šimkova, M., Květoňb, J., Vráblová, M., Kubásek, J., \& Šantrůček, J. (2018). Seasonal Variation of $\delta^{18} \mathrm{O}$ and $\delta^{2} \mathrm{H}$ in Leaf Water of Fagus sylvatica L. and Related Water Compartments. Journal of Plant Physiology, 227, 56-65. https://doi.org/10.1016/j.jplph.2018.03.009

Roden, J. S., Lin, G. L., \& Ehleringer, J. R. (2000) A Mechanistic Model for Interpretation of Hydrogen and Oxygen Isotope Ratios in Tree-Ring Cellulose. Geochimica et Cosmochimica Acta, 64, 21-35. https://doi.org/10.1016/S0016-7037(99)00195-7

Scheidegger, Y., Saurer, M., Bahn, M., \& Siegwolf, R. T. W. (2000). Linking Stable Oxygen and Carbon Isotopes with Stomatal Conductance and Photosynthetic Capacity: A Conceptual Model. Oecologia, 125, 350-357. https://doi.org/10.1007/s004420000466

Seidel, F., Lopez, C. M. L., Oikawa, A., \& Yamanaka, T. (2019a). Seasonal Nitrogen Partitioning in Japanese cedar (Cryptomeria Japonica, D. Don) Tissues. Plant and Soil, 442, 511-529. https://doi.org/10.1007/s11104-019-04178-8

Seidel, F., Lopez, C. M. L., Celi, L., Bonifacio, E., Oikawa, A., \& Yamanaka, T. (2019b). N Isotope Fractionation in Tree Tissues during $\mathrm{N}$ Reabsorption and Remobilization in Fagus crenata Blume. Forests, 10, 330. https://doi.org/10.3390/f10040330

Shestakova, T. A., Voltas, J., Saurer, M., Siegwolf. R. T. W., \& Kirdyanov, A. V. (2017). Warming Effects on Pinus sylvestris in the Cold-Dry Siberian Forest-Steppe: Positive or Negative Balance of Trade? Forests, 8, 490. https://doi.org/10.3390/f8120490

Sternberg, L., Dero, M., \& Savidge, R. (1986). Oxygen Isotope Exchange between Metabolites and Water during Biochemical Reactions Leading to Cellulose Xynthesis. Plant Physiology, 82, 423-427. https://doi.org/10.1104/pp.82.2.423

Valentini, R., Anfodillo, T., \& Ehleringer, J. R. (1994). Water Sources and Carbon Isotope Composition $\left(\delta^{13} \mathrm{C}\right)$ of Selected Tree Species of the Italian Alps. Canadian Journal of Forest Resources, 24, 1575-1578. https://doi.org/10.1139/x94-205

Voltas, J., Lucabaugh, D., Chambel, M. R., \& Feerrio, J. P. (2015). Intraspecific Variation in the Use of Water Sources by the Circum-Mediterranean Conifer Pinus halepensis. New Phytologist, 208, 1031-1041. https://doi.org/10.1111/nph.13569

Walker, C. D., Brunel, J. P., Dighton, J., Holland, K., Leaney, F., McEwan, K., Mensforth, L., Thorburn, P., \& Walker, C. (2001). The Use of Stable Isotopes of Water for Determining Sources of Water for Plant Transpiration. In M. Unkovich, J. Pate, A. McNeil, \& J. D. Gibbs (Eds.), Stable Isotope Techniques in the Study of Biological Processes and Functioning of Ecosystems (pp. 57-89). Netherlands: Springer Science \& Business Media. https://doi.org/10.1007/978-94-015-9841-5_4

White, J. C., \& Smith, W. K. (2015). Seasonal Variation in Water Sources of the Riparian Tree Species Acer negundo and Betula nigra, Southern Appalachian Foothills, USA. Botany, 93, 519-528. https://doi.org/10.1139/cjb-2015-0003 